原著

滑動性追従眼球運動和よび視運動性眼反射の受動的反応の比較

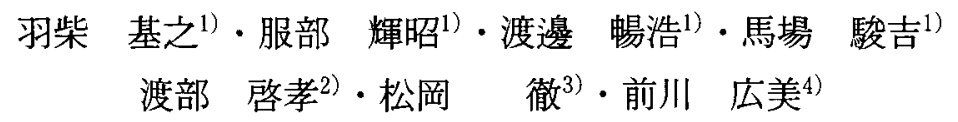

\title{
Comparison between Passively Evoked Smooth Pursuit Eye Movements and Optokinetic Ocular Reflex
}

\author{
Motoyuki Hashiba $^{1)}$, Teruaki Hattori1), Nobuhiro Watanabe ${ }^{1)}$, Shunkichi Baba ${ }^{1)}$, \\ Hirotaka Watabe ${ }^{2)}$, Tohru Matsuoka ${ }^{3)}$, Hiromi Maekawa ${ }^{4)}$ \\ 1) Department of Otorhinolaryngology, Nagoya City University Medical School \\ 2) ENT Clinic, NTT Tokai General Hospital \\ 3) ENT Clinic, Johsai Municipal Hospital of Nagoya City \\ 4) ENT Clinic, Higashi Municipal Hospital of Nagoya City
}

In 7 healthy subjects, horizontal smooth pursuit eye movements (SPEM) and horizontal optokinetic ocular reflex (OKR) were measured in the dark under the passive attitude which subjects tried to fixate at the center of a screen (passive SPEM and passive OKR). A sinusoidal spot target oscillation and a sinusoidal narrow-band (7 deg bandwidth in vertically) pattern oscillation were employed to elicit passive SPEM and passive OKR, respectively. The pattern consisted of randomly arranged fine dots. For the control, SPEM was elicited by following the spot target actively (active SPEM). Nine sinusoidal oscillations with frequencies ranging from 0.2 to $1.6 \mathrm{~Hz}$ and peak velocities ranging from 19 to $150 \mathrm{deg} / \mathrm{s}$ were employed. Passive OKR was clearly demonstrated, and the velocity gain of passive OKR was slightly lower than that of active SPEM under frequencies less than $0.8 \mathrm{~Hz}$ and was similar at $1.6 \mathrm{~Hz}$. Common frequency-phase profiles were observed between passive OKR and active SPEM. However, the velocity gain of passive SPEM was much lower than that of passive OKR and depended on the amplitude of target oscillation i.e. the lower amplitude provided a higher gain. We concluded that poor response of the passive SPEM and amplitude dependency of the passive SPEM response was caused by the absence of assistance from the voluntary saccade in the passive attitude. The SPEM response for a small moving target may depend on the voluntary saccade function which maintains a target at the fovea while supplementing SPEM.

Key words: passive optokinetic ocular reflex, passive smooth pursuit eye movements, random-dot pattern, sinusoidal wave

1) 名古屋市立大学医学部耳鼻咽喉科学教室

2) NTT 東海総合病院耳鼻咽喉科
3）名古屋市立城西病院耳鼻咽喉科

4) 名古屋市立東市民病院耳鼻咽喉科 


\section{はじめに}

一般汇眼前をゆっくりと移動する視覚対象物を 追視する際に見られる滑らかな眼球運動を滑動性 追従眼球運動 (smooth pursuit eye movement: SPEM）と呼んでいる。一方，眼前を次々に横切 る視覚刺激（視運動刺激, optokinetic stimulus: OKS）によって誘発される眼球運動は視運動性 眼振としてょく知られている。しかし，パターン による視覚刺激を小さい振幅で左右に動かすと， 急速相の欠如した眼球運動が誘発されるので, 眼 球運動は必ずしも眼振の形態をとるとは限らな い。そこでここではより一般的な用語として， OKS Kより誘発される眼球運動のうち急速相を 除いた僬い眼球運動成分を表す言葉として視運動 性眼反射 (optokinetic ocular reflex: OKR) を用 いる。この両者は同じ視覚誘発性の眼球運動であ るが多くの点で相違がみられる。

まず両者は大きな種差があり，OKR が動く目 を持つすべての動物に存在するといわれているの に対して，SPEM は哺乳類の中でもヒトやサル などのよらな中心窩視の発達した動物にの文備わ った機能である1)。の意味から，OKRの方が 起源の古い眼球運動であるといえる。

また, OKSは視野全体に加えられる状態が眼 球運動の解発に最も有効である。実験的にあるい は臨床検查では OKR を解発する手段として，大 きなスクリーンに等間隔に配置した線条を投影し 回転させる手法が用いられている。しかし，自然 な状態では周囲の物体が一様に回転するよらな事 態は極めて希であるので，視野全体に対する OKS が生じる状況は, 自分の動きに伴って周囲 の相対的な運動が生じた場合に限られる。この意 味に扎いて，OKR は自己の運動時に VOR と同 時に働き, 視線の保持に役立つのが本来の機能で あるといえる。一方, SPEM は小さな視標の動 きに対しても起こるので，自己の運動時だけでな く頭が静止している状況でも機能し，視標の移動 速度に眼球運動速度を近つけることにより網膜に おける視標の像の移動速度を最小に保ち，良好な 視覚を確保するのに役立っている。

一般に SPEM はその解発に意志の力を要する と言われているが，OKR は意志関わらず受動 的にも解発される。また OKRは, 空間に固定し た視標が存在する条件では，これを注視すること
により著明に抑制することができる。しかし，空 間固定の視標が存在しない条件では, 仮想の点を 注視しょうとしても，ごく部分的にしか抑制する ことができない2)。この意味で，OKR は SPEM より反射的な性格を持ら，また SPEM は OKR に比較して随意的な運動であるとい方る。

以上のような OKR と SPEM の違いを説明す る有力な知見として, OKR が眼球運動の解発の 時間経過から 2 つの成分からなることが知られる よらになった。ここでは両者を表す言葉として rapid-rise OKR と slow-rise OKR ${ }^{3)}$ を用いること にする。前者は OKS の開始とともに急速に立ち 上がる反応であり，中心窩視が発達した動物で優 位にみられ，一般には OKR の内の SPEM 成分 と理解されている4)。後者は, OKS の開始に遅れ て反応が立ち上がり，OKSの終了後も反応が持 続する (optokinetic after-nystagmus: OKAN と して知られている)。さらに後者は, 中权の velocity storage mechanism（VSM）を介する反 応であり，VOR システムと slow-rise OKR シス テムは同じVSM を共有していると考えられてい る5)6)。中心窩視の発達していない家兔等の哺乳 類では， slow-rise OKR のみがみられることか ら, 前に述べた OKR と SPEM の差異は OKR の slow-rise 成分の働きで説明されてきた。

しかしながら, OKR と SPEM の関係につい て上述のような理解では説明できない部分も多 い。例えば，一般に SPEM は解発に意志の力を 要すると言われているが，完全暗所下で点視標を 動かすを, 被験者に視標を追視しない上うに指示 しても，眼球運動が誘発される7)。すなわ， SPEM もある程度は受動的に誘発されるので slow-rise OKR だけが受動的反応を引き起こして いるのではない。また，誘発される眼球運動の最 大速度が，点視標による刺激よりパターン刺激で は速いことが報告されている8)。ヒトでは OKR は極めて短時間で最大速度に達するので, この最 大速度の違いをゆっくり立ら上がる slow-rise OKR の関与で説明することはでさない。また， SPEM でも後眼振が誘発されるとの報告もあ $\eta^{9)}$ ，ヒトでは SPEM の中权経路と slow-rise OKR の系につながりがある可能性がある。さら に, SPEM の潜時と rapid-rise OKR の潜時が異 なるとの報告むある10)。また，臨床例で SPEM 
と OKR の障害の程度が異なる症例が報告されて いる。すなわち， SPEM の障害が著明であって も OKR が正常な症例や，逆に OKR の障害が著 明であるにも関わらず SPEM が正常な症例が報 告されている11。これらの報告はSPEM と rapid-rise OKR は異なるシステムで駆動されて いる可能性を示している。

本研究の目的は, 被験者が視標を追視する意志 を持たないとき，受動的に誘発される OKR およ び SPEM の特性と被験者が能動的に点視標を追 視した場合の SPEM の特性を比較し， SPEM の 解発に和ける意志の関与の詳細之, OKR SPEM の本質的な違いを明らかにすることにあ る。

\section{方 法}

被験者は, 視力に問題なく, めまいや難聴の既 往のない健康成人 7 名（男性 5 名, 女性 2 名, 年 齢27歳から43歳）である。半径 $50 \mathrm{~cm}$ の白色半 球ドームスクリーンに赤色の点視標（直径約 3 $\mathrm{mm}$ ）およびランダムドットパターンを投影する 視覚刺激装置を用いた(第一医科製)。これをパー ソナルュンピュータ（NEC PC9821）で制御し, 点視標打よびパターンを水平万向に動かした。視 覚刺激には赤色レーザーで投影した点視標（spot） と上下方向に幅の狭い（上下 $7^{\circ}$, 水平方向 $180^{\circ}$ ) ランダムドットパターン (pattern-band) の 2 種 類を用いた。ランダムドットパターンは直径 2 〜 $7 \mathrm{~mm}$ の白色の点をランダムに投影したもので, 点の密度は $220 / 100 \mathrm{~cm}^{2}$ である。すべての実験は 暗所下で行った。被験者の頭部は㖽受けを使用し て固定した。被験者注対する指示は，受動的 (passive) な状態では正面視を保ちできるだけ目 を動かさないよらに指示した。しかし，故意に眼
の焦点をスクリーンの手前や後方に合わせ，点視 標やパターンをぼかすことは禁じた。また比較の ために点視標を能動的 (active) に追視した場合 についても記録した。視覚刺激時間は 30 秒とし, その内の前半の 20 秒を解析した。表 1 に示す， 4 周波数 $(0.2,0.4,0.8,1.6 \mathrm{~Hz})$ と 3 振幅 $(15$, $\left.7.5,3.75^{\circ}\right)$ を組み合わせた 9 種類の正弦波を使 用した。刺激波の最高速度は $19,38,75,150^{\circ}$ /sec の 4 種類であり, 視覚刺激により誘発され る眼球運動が速度入出力系であると考えられるの でそれぞれの最高速度毎汇周波数特性を求め た。

眼球運動の記録には, 頭部に固定した CCD ビ デオカィラで近赤外光の照明下に眼球を撮影し, その画像を高速画像処理により瞳孔の重心点を計 算することで, 眼球位置を求める装置（ISCAN system）を使用し，両眼視の状態での左眼の眼球 運動を記録した。サンプリング周波数は $120 \mathrm{~Hz}$ で眼球運動データは DA (digital-analog) 変換さ れ一旦アナログデータとして出力される。眼球運 動記録の校正は周波数 $0.2 \mathrm{~Hz}$, 振幅 $15^{\circ}$ の spot 視標の正弦波を追従させて行った。眼球運動の信 号と視標の運動は一旦アナログデータレコーダ (TEAC MR30) に收録した後, $200 \mathrm{~Hz}$ でアナロ グデジタル変換を行いコンピュータに取り込ん だ。

眼球運動の解析には独自に開発した saccade （眼振急速相を含む）除去プログラムを用い12）, パーソナルュンピュータ（PC9801 BA3）による 自動解析を行った。 saccade 除去の後, 前後の滑 らかな眼球運動成分の速度を平均化した直線で saccade 除去部分を補完し, 滑らかな眼球運動成 分のみをつなぎあわせた波形 (slow cumulative

表 1 視覚刺激に用いた正弦波の一覧

\begin{tabular}{c|cccc}
\hline & \multicolumn{4}{|c}{ Maximum velocity (deg./sec) } \\
\hline Amplitude (deg.) & $0.2 \mathrm{~Hz}$ & $0.4 \mathrm{~Hz}$ & $0.8 \mathrm{~Hz}$ & $1.6 \mathrm{~Hz}$ \\
\hline 3.75 & - & - & 19 & 38 \\
7.5 & - & 19 & 38 & 75 \\
15 & 19 & 38 & 75 & 150 \\
\hline
\end{tabular}

4 つの周波数 $(0.2,0.4,0.8,1.6 \mathrm{~Hz})$ と 3 つの振幅 $\left(15,7.5,3.75^{\circ}\right)$ を組み合わせた 9 種類の正弦波を使用し た。刺激波の最高速度は $19,38,75,150 \%$ sec の 4 種類となる。 
Spot (Passive)

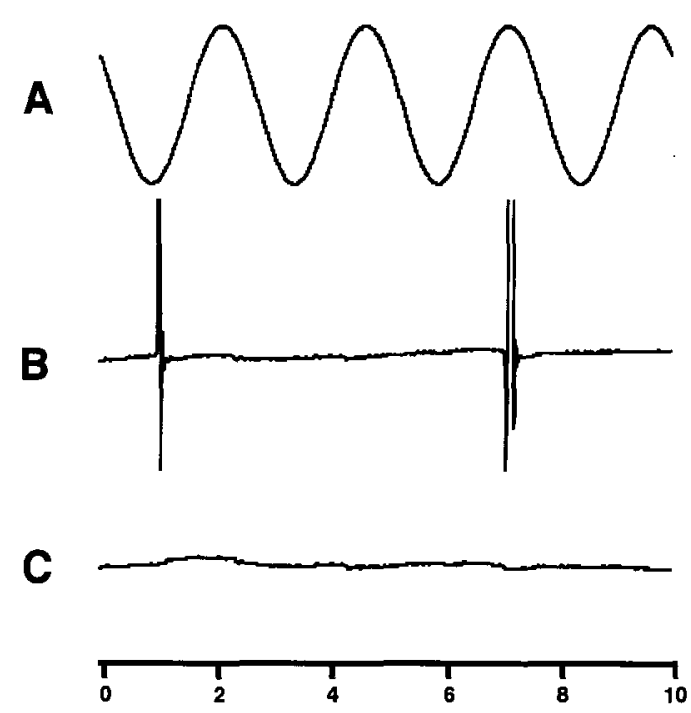

Pattern-band (Passive)

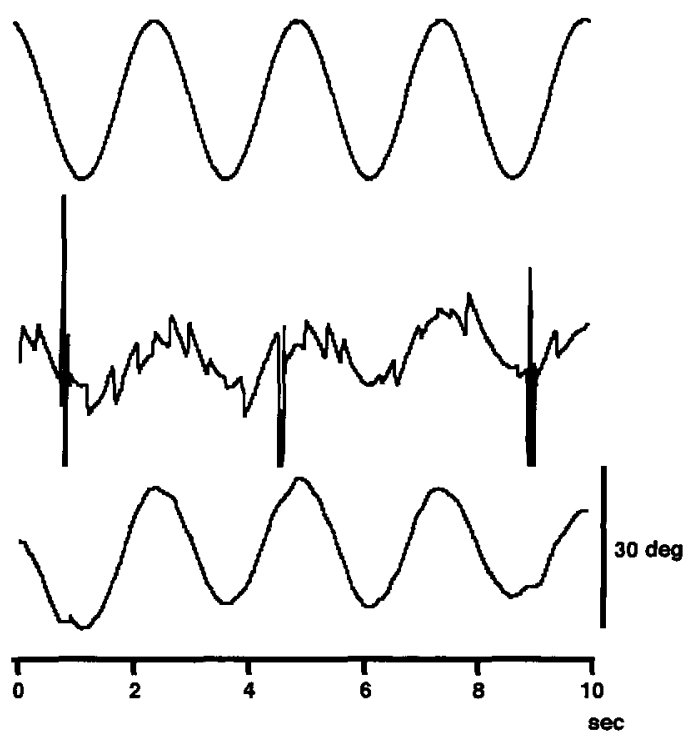

図 1 受動的反応の一例 $\left(0.4 \mathrm{~Hz}\right.$, 掁幅 $\left.15^{\circ}\right)$

A: 視覚刺激（位置）, B: 眼球運動（位置), C: SCEP を示す。左側は spot, 右側は pattern-band 刺激の 結果を示す。

eye position curve: SCEP) を作成した。20秒間 の刺激波の速度波形および SCEP の速度波形を 高速フーリェ変換することにより，それぞれの周 波数に括ける刺激波の速度に対する滑らかな眼球 運動速度の利得 (gain) と位相差 (phase) を求 めた。

\section{結果}

図 1 に示すように, spot（passive）の条件では 誘発される眼球運動は小さい。しかし, 眼球運動 を積極的に止めようとしているにも関わらず, pattern-band (passive) の条件では, 非常に大き な眼球運動が誘発されている。 saccade を除去し て再構築した SCEP では刺激波形と同期した波 形が再現されている。

同じ刺激周波数で比較すると, pattern-band (passive) の条件では振幅の大きさに関わらず良 好な反応が観察されるが, spot (passive) の条件 では振幅が小さくなるにつれて反応が良好になる 現象が認められている（図2）。

さらに, 図 3 に示すよらに, spot (passive) で 反応性が良好な被験者では, 振幅が大きい刺激に 対して, 視標が中心付近を通過するときのみに良
好な眼球運動が誘発された。そのために，SCEP の波形の正弦波の頭の部分がつぶれて雪むのが観 察された。同じ振幅・周波数の pattern (passive) の条件ではこの様な現象は見られていない。

以上のことから, spot (passive) の条件では, 振幅が小さく被験者の仮想の注視点（スクリーン のセンター）から視標があまり離れない刺激条件 で, 眼球運動が比較的良好飞誘発される傾向が見 られた。

定量解析の結果, 利得は $0.8 \mathrm{~Hz}$ をでの周波数 $(0.2,0.4,0.8 \mathrm{~Hz})$ では, pattern-band (passive) は spot (active) を下回るが, $1.6 \mathrm{~Hz}$ に括いては 差が見られない。spot (passive) の条件は他の条 件に比較して利得が低く，すべての条件で 0.5 以 下であり，特に刺激速度の速い条件下では 0.1 以 下であった。また, spot (active) と pattern-band (passive) の条件では同じ最高速度の条件で比較 すると周波数が高くなるに従って利得が低下する 傾向が見られたが，spot (passive) の条件では周 波数の上昇に従って逆に利得が上昇している（図 $4 \mathrm{~A}, \mathrm{~B}, \mathrm{C})$ 。同一周波数で比較した場合に spot (active) と pattern-band (passive) の条件では刺 
Equilibrium Res Vol. 56(5)

Spot (Passive)

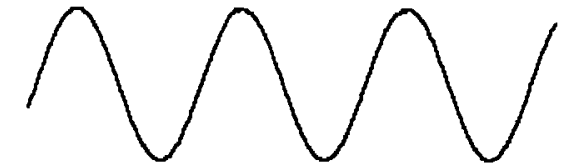

$15 \mathrm{deg}$

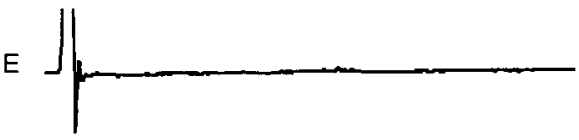

$7.5 \mathrm{deg}$
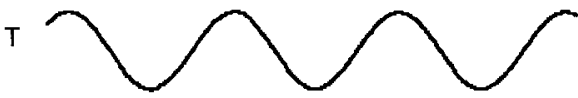

$\mathrm{E}$

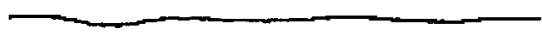

$3.75 \mathrm{deg}$

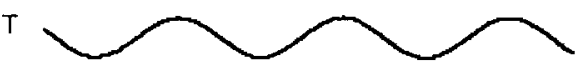

E

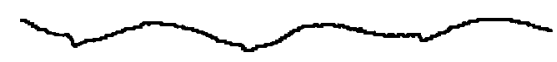

Pattern-band (Passive)
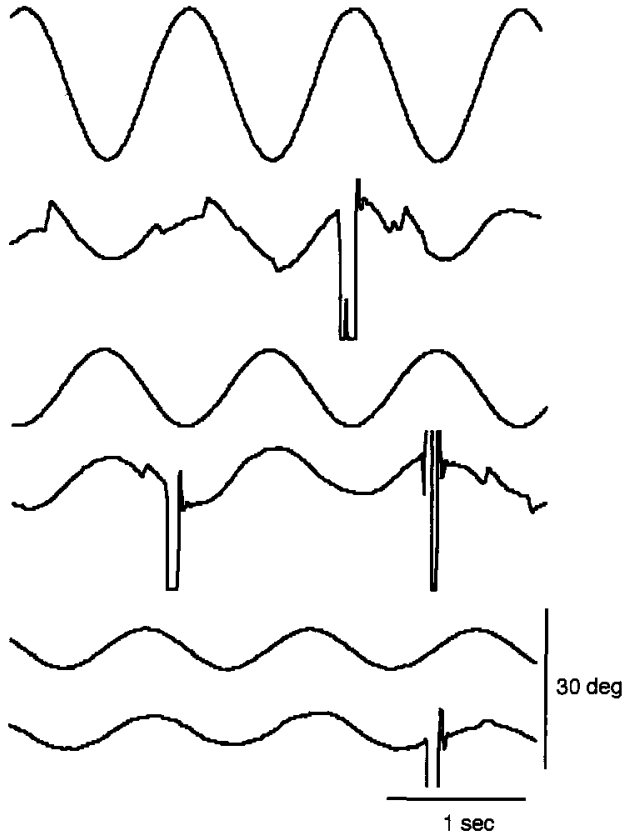

図 2 各振幅での原波形の一例 $(0.8 \mathrm{~Hz})$

上段から振幅 $15,7.5,3.75^{\circ}$ の記録。T: 視覚刺激（位置）、E: 眼球運動（位置）を表す。左側は spot， 右側は pattern-band 刺激の結果を示す。

\section{Spot (Passive)}

A

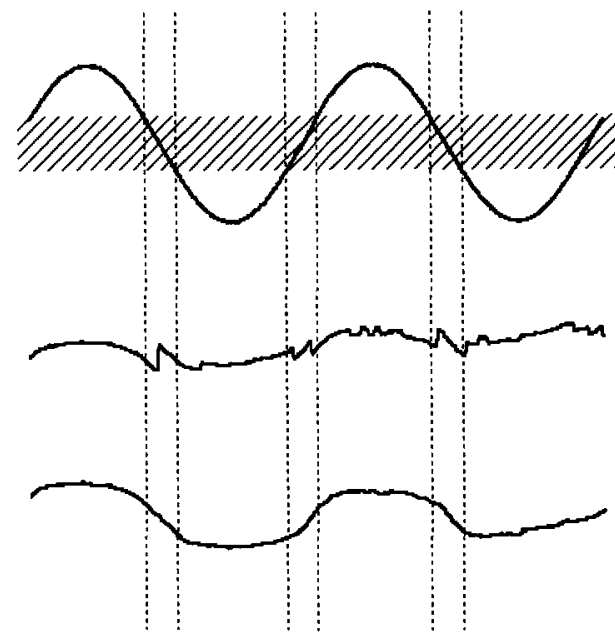

Pattern-band (Passive)
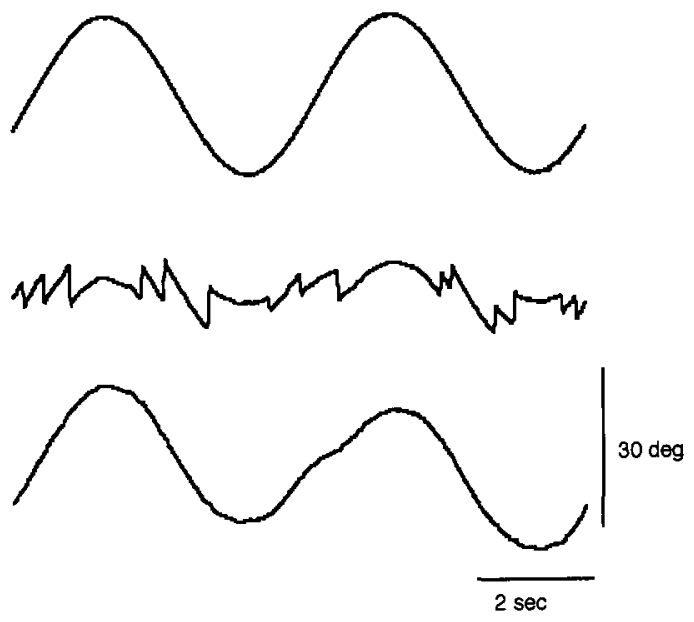

図 3 spot 刺激で反応の上い被験者の記録例 $\left(0.2 \mathrm{~Hz}\right.$ ，振幅 $\left.15^{\circ}\right)$

A: 視覚刺激 (位置), B: 眼球運動（位直）, C: SCEP を示寸。左側は spot, 右側は pattern-band 刺激の 結果を示す。斜線部分は中心から $\pm 5^{\circ}$ の範囲を示す。 
A
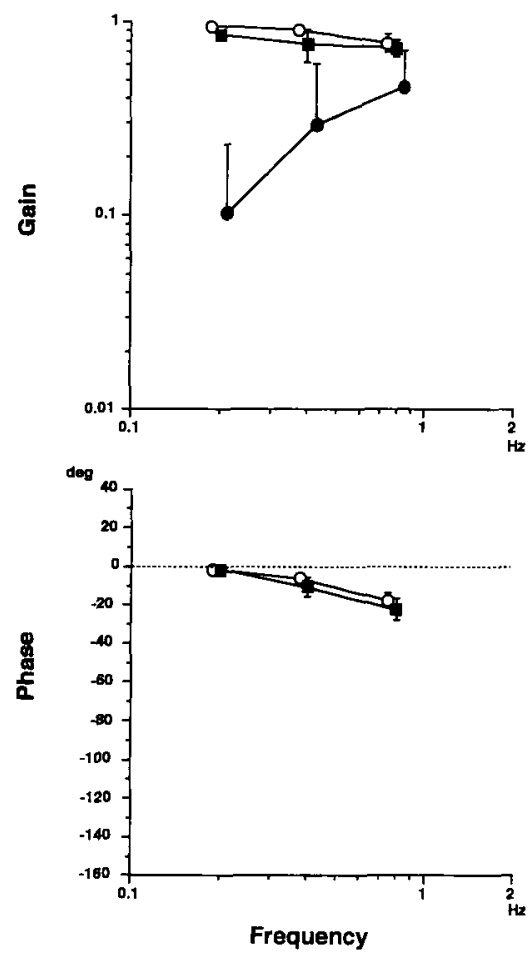

C
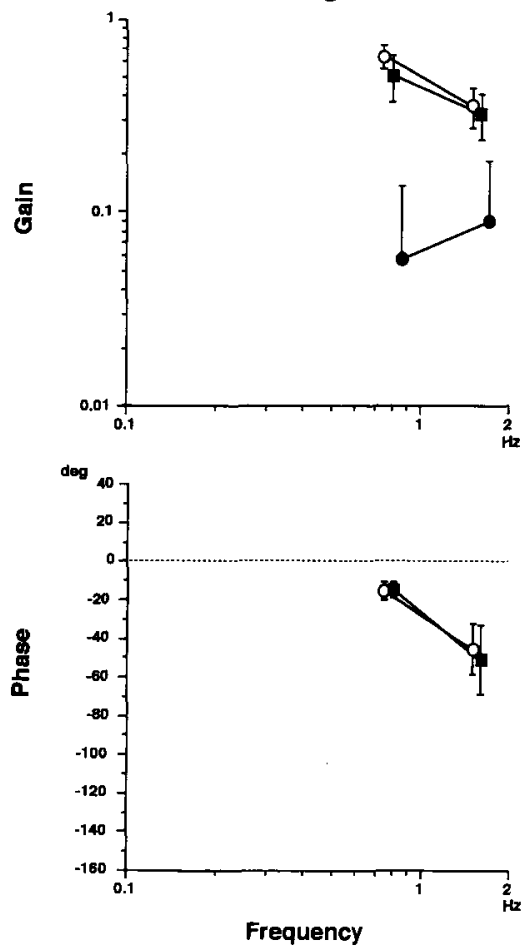

B
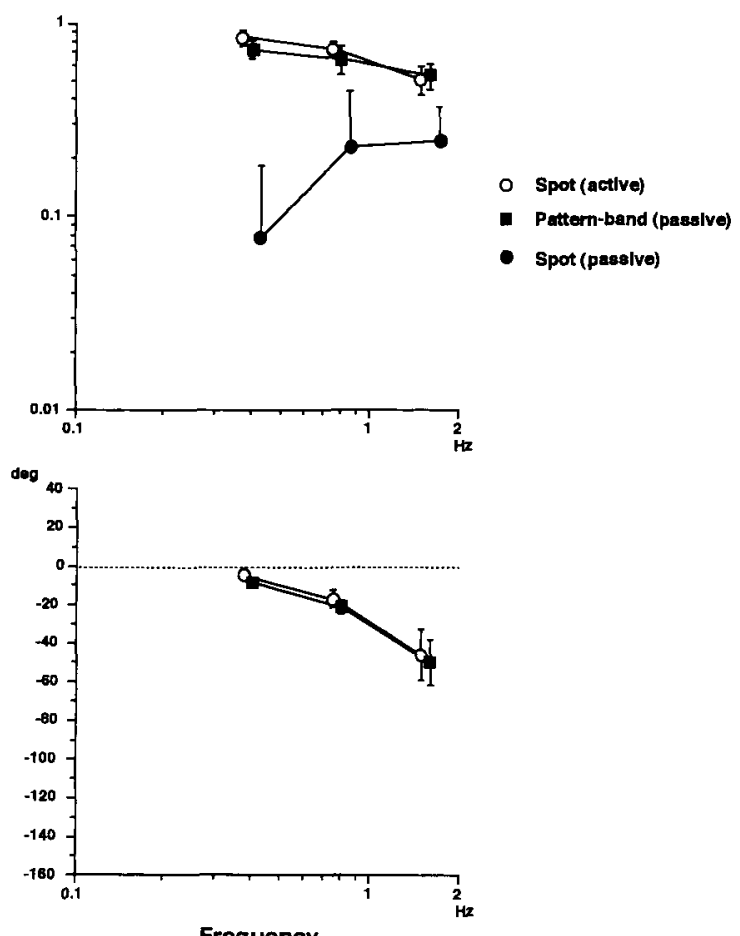

Frequency

D

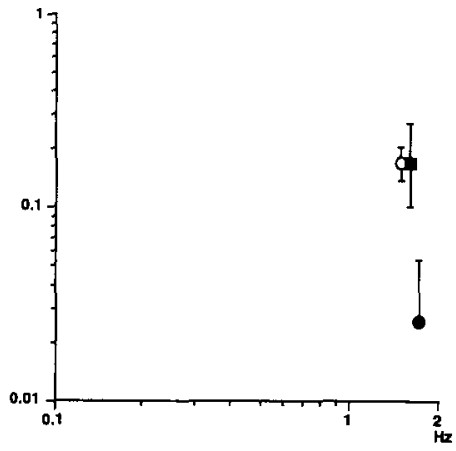

deg

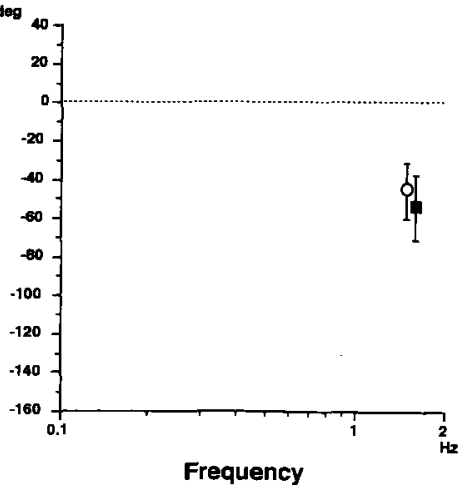

図 4 利得 - 位相特性 (ボード線図)

刺激の最高速度每纪，A: $19^{\circ}$ $/ \mathrm{sec}, \mathrm{B}: 38^{\circ} / \mathrm{sec}, \mathrm{C}: 75^{\circ} / \mathrm{sec}$, D: $150 \%$ sec を示す。白丸： spot 刺激を能動的飞追視し たとき（暗所下の通常の視標 追跡），黑四角：patternband 刺激 (受動的), 黒丸: spot 刺激（受動的）を示す。 各上段は利得，下段は位相の グラフで, 各点は平均值, エ ラーバーは標準偏差を示す。 spot 刺激（受動的）のデー タについては, 利得が著しく 低くSCEP の振幅が小さい ので位相のデータは削除し た。また，縦軸が対数目盛で 負の值が表示できないため， 利得のエラーバーはプラス側 のみを表示した。 


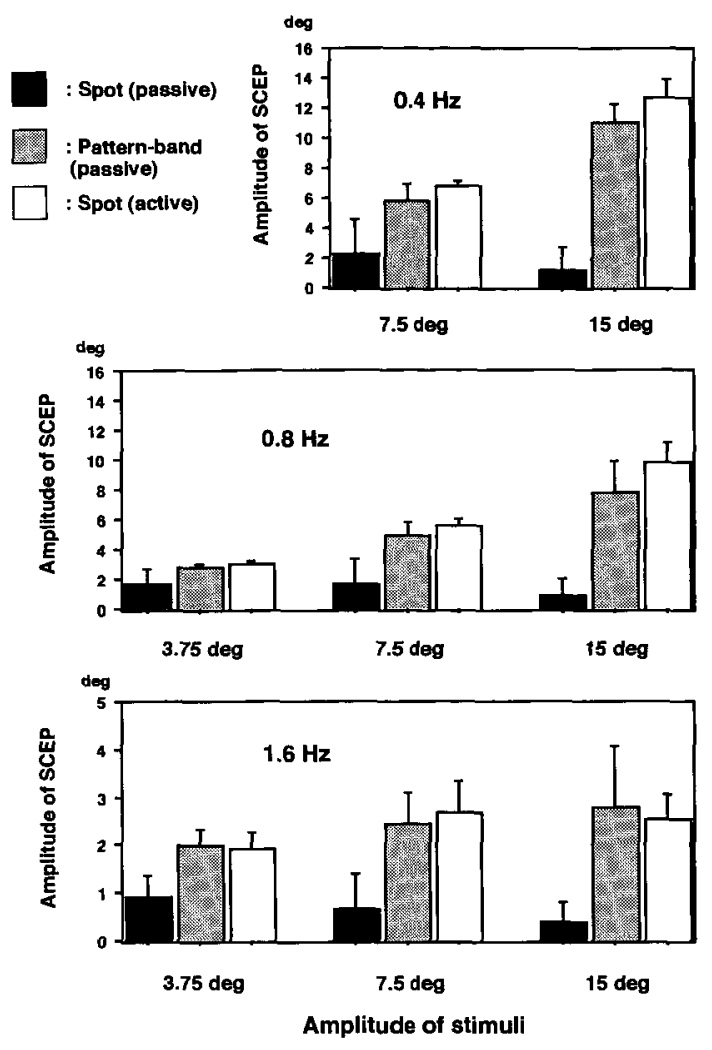

図 5 SCEP 振幅

$0.4,0.8,1.6 \mathrm{~Hz}$ の各周波数每比, 刺激振 幅別の SCEP の振幅とその標準偏差を示 す。

激波の振幅が大きくなり最高速度が大きくなるに つれて，SCEP の振幅の絶対値が増加するのに対 して spot (passive) の条件では逆に減少した（図 $5)$ 。

位相の解析では, pattern-band (passive) の位 相特性は spot (active) と極めて類似しており差 を認めなかった。をた，速度を一定にして比較し た場合, 高い周波数になるほど位相の遅れが著明 となった。その值は $0.8 \mathrm{~Hz}$ で約 $20^{\circ}, 1.6 \mathrm{~Hz}$ で 約 $50^{\circ}$ であり, 今回実験した速度範囲では最高 速度に依存せず周波数にのみ依存した。

\section{考 察}

被験者に対してできるだけ眼を動かさずに正面 視を保つように指示しても, spot 刺激でも偪の 狭い $\left(7^{\circ}\right)$ pattern 刺激でる眼球運動が誘発され ることが今回の実験で示された。しかし，両者の 反応はいくつかの点で異なっていた。 $7^{\circ}$ といら幅の狭い pattern-band 刺激を用いて も良好な反応が見られたことから，周辺視野への 視運動刺激が受動的反応を引き起こすために必ず しも必要でないことがわかる。視運動性刺激によ る眼球運動解発において最も感度の高い部位は視 野の中心部であることが知られており 13)14), 受動

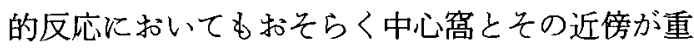
要であると考えられる。さらに，ヒトではもとも と slow-rise OKR の成分が小さい上に，今回用 いた刺激が正弦波刺激であることから，右向きと 左向きの速度入力が交互にVSM に入力され蓄積 されるので，左右の速度成分がキャンセルされ slow-rise OKR は泀とんど現れてこない。別の表 現をすれば，VSM は一種の積分回路（一次遅れ 系）であるから交流信号に対しては low-pass filter とみなせるので，正弦波信号が VSMを通 過したときの利得次の式で表される。

時定数を $\mathrm{T}$ とすると周波数 $\mathrm{f}$ の信号に対する積 分回路（一次遅九系）の利得 A は

$A=\frac{1}{\sqrt{1+(2 \pi f T)^{2}}}$

で表される。

ここで, ヒトのVSM の時定数 T は約20秒程 度と報告されているので15)，利得は $0.2 \mathrm{~Hz}$ $0.04,0.4 \mathrm{~Hz}$ で0.02, $0.8 \mathrm{~Hz}$ で $0.01,1.6 \mathrm{~Hz}$ で 0.005 となり，本実験に用いた周波数の範囲では slow-rise OKR は極めて小さく，得られた眼球運 動は汪とんど rapid-rise OKR のみであると考党 られる。従って，VSM は受動反応対して必ず しも関与するものでないことがわかる。

ヒトの OKR がその眼球運動の解発の時間経過 から 2 つの成分に分けられることはすでに述べた ('rapid-rise' and 'slow-rise'3), 'early' and 'late'1)。 しかしこの他にもOKRを2つの成分に分類する 試みは数多く行われてきた。'look' and 'stare', 'active' and 'passive', 'foveal' and 'retinal', 'cortical' and 'subcortical' 等であり,これらの分類 はしばしば上記の時間経過による分類と同義的に 解釈されてきたが，そのコンセプトは必ずしも同 一ではないので注意が必要である。例点ば， 'look' and 'stare' あるいは 'active' and 'passive' の分類は視刺激に対する被験者の態度に基つくく分 類であり，本実験の結果でも明らかなように， 
'stare'あるいは 'passive'の条件でも rapid-rise OKR が解発されるのである。

pattern-band の条件では spot (active) の条件 （通常の smooth pursuit）の場合と同様に，周波 数が高くなるに従って利得が低下寸る傾向が見ら れた。しかし， spot (passive) では周波数の上昇 に従って逆に利得が上昇している（図 $4 \mathrm{~A}, \mathrm{~B}$, C)。これは同じ最高速度では周波数が高くなる と刺激波の振幅が小さくなることによると考学ら れる。例えば， $19 \%$ sec の最高速度では，刺激波 の振幅はそれぞれ $0.2 \mathrm{~Hz} て ゙ ~ 15^{\circ}, 0.4 \mathrm{~Hz}$ で $7.5^{\circ}$, $0.8 \mathrm{~Hz}$ では $3.75^{\circ}$ 之周波数の上昇に従って減少 している。同一周波数での比較では, spot（active) と pattern-band (passive) の条件では刺激 波の振幅が大きくなるに従って（最高速度が大き くなるに従って)，SCEP の絶対值の増加が見ら れるが, spot (passive) の条件では逆に SCEP の減少が見られ，刺激波の振幅が小さい汪ど SCEP の振幅が大さい（図 5 )。さらに, spot (passive) で反応性が良好な被験者の例では，振 偪が大さい刺激に対して, 視標が中心付近を通過 寸るときのみに良好な眼球運動が誘発される現象 が見られたことから（図 3 ), spot (passive) で は刺激波の振幅が小さく，視標が視野の中心部で 動くときに利得が大きくなることがわかる。すな わち, この意味で点視標による受動的反俯は振幅 依存性であるといえる。

視覚刺激に対する受動的反応と能動的反応では smooth な眼球運動成分の力向と saccade の方向 の関係が異なる。能動的反応，すなわら通常の視 標追跡眼運動では saccade は smooth な眼球運動 が足りない部分を補うように働くので， smooth な成分と saccade は同じ方向に向から。一方, 受動的反応では, saccade は smoothな眼球運動 で偏位した眼位を中心方向に引き戻すよらに起こ るので, smooth な成分と saccade は逆方向に向 から。速度の遅い点視標を追視する場合でも， SPEM の gain は1より小さいことが報告されて いる16)。つまり, SPEM のみの追従では視標の 像は徐々に中心窩から離れてしまらことになる。 Barnes と Hill7) は，中心から等間隔で離れた一 対の点視標に対する能動的な反応と受動的な反応 について調べ，いずれの場合も点視標が中心部か ら離れるに従って pursuit gain が低下寸ることを
報告している。従って，良好な SPEM を維持す るためには常に saccade の補助により，視標を 中心窩の近傍に捉文て括く必要がある。受動的反 応では saccadeの補助が行われないので, 視標 がスクリーンのセンター付近に存在するときの み，中心窩付近に視標の像が投影されるので SPEM が誘発されたものと考えられる。このた め, 刺激の振幅が小さい場合に良好な反応が得ら れるといら振幅依存性の特性となる。一方, pattern 刺激の場合には pattern が十分に細かけれ ば， saccade のアシストがなくても中心窩には継 続的な視覚的速度入力が存在することになり, 振 幅依存性とはならない。Collewijn と Tamminga ${ }^{17)}$ は上下に $10^{\circ}$ 離れた視標の中心に視標をイメー ジさせこれを追視させた場合，バックグラウンド に模様があると，模様のない場合に比較して著し くSPEM の利得が低下することを報告してい る。すなわち，中心䆟に視標を捉兄ていない状態 の SPEM は, 眼球運動に伴い逆方向に動くバッ クグラウンドの模様が中心窩の受動的視覚入力と なり著しく妨げられると考えられる。この様に考 えてくると，点視標に対する SPEM は，視標を 中心窩に捉克る役割を担っている随意性の saccade system の機能に依存していることが理解さ れる。このことは， SPEM が中心窩視の発達に 伴って備わってきた機能であると同時に，随意性 の saccade system もまた中心裔に視覚対象を捉 える機能として，中心窩視の発達とともに現れて きた機能である18) ことからも理解し得る。従来 SPEM と saccade はその中枢経路の違いなどか ら全く独立したわのとして考光られてきたが，点 視標に対する SPEM に関してはその機能に saccade が関与していると考えなければならない。 すなわち，被験者がなるべく眼を動かさないよう に努力すると，視標が中心窩付近を通過するとき に一過性に受動的な SPEM が起こっても，被験 者は逆方向への saccade で視線を元の位置に戻 してしまらので，視標は中心简から外れ SPEM の利得は低下し SPEM は継続しなくなる。反対 に被験者が視標を眼で追招うとしているときに は, 視標が中心䈑から外れると直ちに saccade によって再び視標を中心窝に捉えるので，視標は 中心䆟に捕捉され続け SPEM が継続する。この よらに saccade が意志により制御されているこ 
とから, 少なくともSPEM に和ける意志の関与 の一部は随意性の saccade の関与に置き換光る ことができる。

pattern-band 刺激は全視野刺激でないにも関 わらず，しかる被験者になるべく眼を動かさない よらに指示した passive な条件にも関わらず，極 めて良好な眼球運動が解発された。これは今回用 いたパターンが細かいランダムドットパターンで あり，細かいパターン刺激を用いたことが良好な 受動反応が得られた原因と考光られる。その利得 は active SPEM よりもやや低いが全体の周波数 特性は極めて類似している。さらに，位相の周波 数特性は汪とんど active SPEM と同じであっ た。刺激波形以正弦波を使用しているので VSM を介する反応である slow-rise OKR はキャンセ ルされ，汪とんど rapid-rise OKR と考学られる。 このような利得と位相の周波数特性から rapidrise OKR は SPEM の系と中枢経路が共通であ る可能性が示唆される。我々はすでに SPEM K 対するバックグラウンドの影響を検討し， SPEM の利得はバックグラウンドによって影響を受ける が，位相特性は変わらないので SPEM と rapidrise OKR は共通の中枢機構を利用している可能 性が高いことを報告しており19)，今回の結果も同 じ結論となった。さらに， spot（active）と pattern-band (passive) の条件で位相特性が同じで あったことから，視覚刺激に対する被験者の態度 の違い (active と passive) は位相特性に影響を 及淩さないと考えられる。

以上のことから，今回明らかになった SPEM と rapid-rise OKR の違いを要約すれば，両者は 基本的な情報処理や中权経路が共通であるが，そ れぞれが対応する視覚刺激の性質，すなわち単独 の点視標であるか連続的に連なる複数の視標（パ ターソ）であるか，によって saccade systemの 役割が異なる点にある。点視標に扣いては随意性 の saccadeにより SPEM を補い視標を常に中心 窩で捉えることが SPEM の維持に不可欠であ り，被験者が視標を追視しようとしなければ随意 性の saccade は起こらないので視標が中心窩か ら外れてしまいSPEM 峙維持できない。一方卡 ターン視標では追従が不十分で視線がずれてもパ ターンが十分に細かければ中心骷への視覚入力は 維持される。また被験者が視標を追視する意志が
無く正面視を維持しようとすると saccade（ある いは OKN 急速相）は視線を正面付近に引き戻す よらに動くが，パーンが十分に細かければ視線 が戻った部位にも同じパターンが存在することに なるので，中心䆟に対する速度入力はやはり継続 的となり，従って受動反応が維持される。

以上の点以外に考慮すべき要素として，パー ン視標を用いる場合には中心窝扣よびその近傍以 外の網膜部位からの入力が存在し，網膜に対する 刺激量が異なることが考えられる。さらに細かい パターン視標を用いても被験者が能動的な場合と 受動的な場合では反応性が異なることから，随意 性の saccade の関与以外にも意志の働く機構が 存在することも事実である。

\section{まとめ}

1. 点視標と上下方向の幅の狭いランダムドッ 卜パターン視標を正弦波で駆動し，受動的に誘発 される眼球運動を定量的に解析した。

2. 点視標刺激とパターン視標刺激はともに受 動的な眼球運動を誘発したが，その程度はパター ン刺激で常に優位であった。

3. 点視漂で誘発される眼球運動は刺激波の振 幅に依存性であり，振幅が小さい汪ど大きな眼球 運動が誘発された。

4.点視標とパターン視標により誘発される眼 球運動の比較から，点視標により誘発される滑動 性追従眼球運動の維持には, 随意性衝動性眼球運 動の補助が必要であると考兄られた。

5. パターン視標の正弦波刺激で誘発される眼 球運動は，中枢の速度蓄積機構（velocity storage mechanism) が関与せず視運動性眼反射の急 速に立ら上がる成分（rapid-rise OKR）と考兄ら れるので, rapid-rise OKR は受動的にも誘発さ れることが示された。

6. 位相特性の解析から視運動性眼反射の急速 に立ち上がる成分（rapid-rise OKR）と滑動性追 従眼球運動は共通の中枢機構を持つと推定され た。

7. 被験者の視標運動に対する態度（能動的か 受動的か）は得られる眼球運動の位相特性に影響 を及ぼさなかった。

\section{謝辞}

本研究は名古屋大学・環境医学研究所・宇宙実 
験センターの研究設備を使用して行った。施設利 用に当たり便宜を図っていただいた，宇宙医学実 験センターの森 滋夫教授に深謝いたします。

本研究の一部は第55回日本平衡神経科学会総会 および第42回日本宇宙航空環境医学会総会にて講 演した。

本研究の一部は文部省宇宙科学研究所, 宇宙基 地利用基礎実験費：「直楾加速度負荷実験装置に よる視・前庭感覚統御機構の解析」(課題番号 U39）を使用して行った。

\section{文献}

1) Carpenter R: Optokinesis and smooth pursuit. In Movements of the eyes. pp 39-68, Pion Limited, London, 1988

2) Murphy BJ, Kowler E, Steinman RM: Slow oculomotor control in the presence of moving backgrounds. Vision Res 15: 12631268,1975

3 ) Morrow MJ, Sharpe JA: Smooth pursuit eye movements. In eds Sharpe JA, Barber HO. The vestibulo-ocular reflex and vertigo. pp 141-162, Raven Press, New York, 1993

4) Howard IP: The optokinetic system. In eds Sharpe JA, Barber HO. The vestibulo-ocular reflex and vertigo. pp 163-184, Raven Press, New York, 1993

5) Raphan T, Matsuo V, Cohen B: Velocity storage in the vestibulo-ocular reflex arc (VOR). Exp Brain Res 35: 229-248, 1979

6) Demer JL, Robinson DA: Different time constants for optokinetic and vestibular nystagmus with a single velocity-storage element. Brain Res 276: 173-177, 1983

7 ) Barnes GR, Hill T: The influence of display characteristics on active pursuit and passively induced eye movements. Exp Brain Res 56: 438-447, 1984

8) van den Berg AV, Collewijn H: Human smooth pursuit: effects of stimulus extent and of spatial and temporal constraints of the pursuit trajectory. Vision Res 26: 12091222, 1986

9) Muratore R, Zee DS: Pursuit after-nystagmus. Vision Res 19: 1057-1059, 1979

10) Gellman RS, Carl JR, Miles FA: Short latency ocular-following responses in man . Vis Neurosci 5: 107-122, 1990

11) Barratt H, Gresty MA, Page NG: Neurological evidence for dissociation of pursuit and optokinetic systems. Acta Otolaryngol (Stockh) 100: 89-97, 1985

12）羽柴基之, 安井桂子, 渡部啓孝, 他：滑動性 追従眼球運動の定量的評価法. 日耳鼻 98: 681-696, 1995

13) van Die G, Collewijn H: Control of human optokinetic nystagmus by the central and peripheral retina: effects of partial visual field masking, scotopic vision and central retinal scotomata. Brain Res 383 : $185-$ 194, 1986

14) Howard IP, Ohmi M: The efficiency of the central and peripheral retina in driving human optokinetic nystagmus. Vision Res 24 : 969-976, 1984

15) Cohen B, Henn V, Raphan T, et al: Velocity storage, nystagmus and visual-vestibular interactions in humans. Ann NY Acad Sci 374: 421-433, 1981

16) Collewijn $H$, Tamminga EP: Human smooth and saccadic eye movements during voluntary pursuit of different target motions on different backgrounds. J Physiol (Lond) 351: 217-250, 1984

17) Collewijn H, Tamminga EP: Human fixation and pursuit in normal and open-loop conditions: effects of central and peripheral retinal targets. J Physiol (Lond) 379: 109-129, 1986

18) Leigh RJ, Zee DS: The neurology of eye movements (edition 2), pp 79-138, FA Davis, Philadelphia, 1991

19) Hashiba $M$, Hattori $T$, Watabe $H$, et al: Influence of superimposed optokinetic stimulus on smooth pursuit eye movements elicited by sinusoidal spot target oscillation. Acta Otolaryngol Suppl (Stockh) 525: 167-171, 1996

$\left(\begin{array}{l}\text { 原稿到着: 平成 } 9 \text { 年 } 3 \text { 月 } 19 \text { 日 } \\ \text { 別刷請求先 : 羽柴基之 } \\ \text { 干467 愛知県名古屋市瑞穂区瑞穂町川澄 } 1 \\ \text { 名古屋市立大学医学部耳鼻咽喉科学教室 }\end{array}\right)$

